\title{
Study on the Formation Affect of the Bible on English Literature Style
}

\author{
Lijuan Sun ${ }^{1}$ \\ ${ }^{1}$ School of Foreign Languages, Zhengzhou University of Industry Technology, Zhengzhou, Henan, \\ 451100
}

KEYWORDS: Formation Effect; The Holy Bible; English Literature Style

\begin{abstract}
The Holy Bible is not only a Christian classics, but also the source language of Western culture, its teachings and ideas laid the cornerstone of Western culture and ideas, the Bible is not only to establish the people's faith in God, led Western countries living custom formation, but also for its support to the spread of eleven languages, especially English language, it had a tremendous impact. These stories passed down through the generations is widely gradually compiled into a fiction story, promote the development of the English language and literature. Bible in English literature in use, an increase of religious literature to improve their cultural values, to explore the English language and literature is inseparable from the story of the Bible study and this paper analyzes the influence of the Bible story of the English language and literature.
\end{abstract}

\section{Introduction}

The Bible is both a record book of religious doctrine, but it is also a connotation of profound literary, philosophical writings. In Western countries, its ideas and philosophy has become an important part of people's consciousness, its language has penetrated into people's daily rhetoric being. It has been the success of the business and education sector leaders conducted a survey and asked which book affected them the most, a quarter of people say the Bible. This is enough to show the impact of the Bible on Western culture and daily life is very deep.

Biblical Christianity is a classic, the impact on the entire culture of the West far-reaching. French writer Victor Hugo once said: England has two books, a Bible, a Shakespeare, England created a Shakespeare, but the Bible was created in England. The Bible is a collection of history, legends, biographies, ethical, legal, statement articles, poems and religious writings of Western social thought and culture had a profound impact. A series of thoughts, beliefs, attitudes and practices advocated in the Bible and so on are popular all levels of people's lives have been branded with the mark of the Bible. Bible Western Christian culture has penetrated into all aspects of social life Country: Western culture festival lot from the Bible; on the court today to witness the oath hand on the Bible; the hotel is also often prepare Bible for passengers; in the United States, presidential inauguration to hand press the Bible oath; people born in the church for the baptism, marriage was held in the church, by the death of the priest buried in the cemetery to pray. Visible in the Western Christian countries, people from birth to death are inseparable from the Bible, therefore, we say that the Bible construct the entire Western society.

\section{The Affect of the Holy Bible on the English language}

Effect of the "The Holy Bible" of the English language is self-evident. First, on the formation of modern English and the "The Holy Bible” Translation is closely related. "King James translation of the Bible" (hereinafter referred to as "translation") was published in 1611, it will come out a have a 
broad impact on society. "Translation" as used in English, simple, clean, concise, beautiful, and highly expressive. It appears not only further establish standardized and unified English, but also greatly expanded its use of surface, so that from the narrow academic language, literature and art in the field came out into the wider community among the thousands of families. "Translation" of success laid the foundation of modern English. Some statistics in this book used the word, although only more than the total number of six thousand five hundred, but the expression of a very rich content. This language also has elegant and noble qualities, and thus has been used as the English model. Since the seventeenth century, generations of British and American people will learn from book nutrients. US President Abraham Lincoln's speech for its concise, profound and beautiful known for his literary equipment is a "translation"; poet Walt Whitman is the new rhythm from "translation" from the inspired.

"Translation" is not only laid the foundation of modern English, and the input of fresh blood for the English, adding a large number of idioms, proverbs, allusions words, derivatives, etc., to enrich and develop and improve this language. First, the "translation" in circulation in the formation of a large number of idioms, idioms these vivid, modern English has become an important part. the apple of the one's eye (the eye pupil) from the "Old Testament Bible • Verses" Chapter 17, Keep me as the apple of the eye. (beg you to protect me as the eyes of the pupil. Another "Shen Deuteronomy "Chapter 32, there .He kept him as the apple of his eye. (protect his protection as the eyes of the pupil.) now translated apple represents something special treasure Another example:.... an eye for an eye (an eye for an eye) in the "The Holy Bible" appears more than once, such as "Old Testament Bible - - Deuteronomy" of 19, Moses was ordered by God to become the slaves of the Israelites in Egypt, the leader of his decree : .The punishment is to be a life for a life, an eye for an eye, a tooth for a tooth, a hand for a hand and a foot for a foot life for life, eye for eye, tooth for tooth,. hand for hand, foot for foot Chinese. An eye for an eye tooth for a tooth is derived from this showing. eye for an eye person in his body.

Secondly, the "The Holy Bible" is in a lot of maxims. The motto in the "translation" in the translation was neat and elegant, very beautiful rhythm, combined with a deep and meaningful content, including women and children has become part of everyday language, such as:. Do as you would be done by, or:. Treat others in the same way as you would like to be treated. Do unto others, do not impose on others. A tree is known by its fruit tree is known by its fruit;. People know their deeds. Better is a neighbor that is near than a brother far off. Better than distant neighbors. As the "The Holy Bible" position of authority in the Christian world, from the motto, "the King James translation of the Bible," tend to have special powers. They often appear in the written and spoken language, forming a kind of folk morality, to a certain extent, affect people's behavior. Such as: persuading beneficence Jie Wu motto When words are many, sin is not absent Loose lips sink ships. All who take the sword will perish by the sword. Playing with fire gets burned.

\section{The Reasons under the Affect of the Holy Bible on the English Literature}

Christianity is the largest religion in the world, about more than one billion Catholics, accounting for a quarter of the world's population, distributed in more than 150 countries and regions. Christian, from creation to now has eighteen hundred years of history, it has a significant impact in the field of political and social life in different historical stages. ${ }^{1}$ Christianity is the main pillar of Western civilization and spiritual, as the Christian Bible is the classic pillars of this column heart. The English language is one of the languages of Christian culture circle, which will inevitably branded with traces of biblical culture. 
The Bible is not only a lot of persuading beneficence Jie Wu language, there are many associated with people, animals, plants, and events such allusions, the use of these languages and allusions can vividly express their views and tendencies. Due to people's hearts desire happiness and look forward to the perfect ending, we will be happy to quote Bible words to express good wishes. This is when parents named the child was particularly prominent. Moses is one of the most popular boys name, because in the Bible, Moses is a hero to save the Jewish people. He is eligible for the guidance of God, he returned to Egypt, to guide the entire Jewish nation through the Sinai desert, migration to other countries, finally got rid of slavery life, to be free. So with the name of Moses, and placed great hopes of parents: the child is willing to brave the firm as a hero, the great cause of achievement. On the contrary, it is naturally a reference to the villain shows the hypocrisy of people hate and hate evil true feelings, like Jedas, Cain and other commonly used to express the people's disgust, hatred feelings.

These languages are lively, easy to understand and remember. These languages typically through ordinary, plain facts or figures reflect the profound meaning, concise and image, it is easy to make people think. In general, this type of language related to animals, people and body parts of Speech majority. For example: Judas kiss, (kiss of Judas; Yu snake in the grass), by the villain in the Bible that thinks Judas meaning expressed most vividly. Another example: a lion in the road0 (trail lions, $\mathrm{Yu}$ formidable obstacle) vivid expression of terrible obstacles. Showing parts of the body through metaphorical meaning of words clearly reflect the attitudes of people. If eye is considered the most important parts of the body, and bright eyes are more vivid and charming, so people are willing to borrow (6 Bible phrase light of oneeyes, to describe their favorite items or people love seen implied metaphor meaning words varied, colorful, and its use is also effective in avoiding the monotony of language, lengthy and heaviness, so loved by the people. visible contains metaphorical meaning of words varied and colorful, which also effectively avoid the use of language the monotonous, tedious and heaviness, so loved by the people.

Creative background of many Western literature, stories and allusions are drawn directly from the Bible, without rhetoric, and without long sentences repeated to highlight the characters, deepen the theme. As previously described, Shakespeare, Bunyan, Bronte, Hardy, Mrs. Stowe, Defoe, Dickens, Hawthorne and other literary giant ho on these languages have been the influence of the Bible. Many works of Western artists but also by the impact of the Bible, such as Leonardo da Vinci's famous painting The Last Supper on based on the Bible story of Judas betrayed Jesus. These writers and artists flashing Bible glorious works loved by the people, these works to a certain extent, the everyday language and the language later writers and creative artists have played a significant role in promoting, so that the Bible further affect the English language.

\section{Conclusion}

Christianity in Britain, the United States and other Western countries entrenched \# Swedish scholar Jacob Burckhardt has pointed out, medieval Europeans and cultural representatives of modern European countries, born with a religious instinct 0, although the loss of this argument biased, but his understanding was vividly disprove Christianity in Western countries deep impact, and in a subtle Christian thought nourishes the human instinct. Because of deep-rooted Christianity in the Western world, as the Christian Bible on many aspects of the classic western countries it has a very profound impact. Its English language influence has penetrated into various aspects of the English language. Although the English language in the history and evolution of the times is in constant change: some old words die out, some of the new words. Herein, it is derived from the biblical idioms, proverbs, stories and word derivatives, etc., with the basic vocabulary of the English 
language, like all great stability. These words have been completely penetrated into all aspects of the English language, of which there are a large number of words in the expression rich in associations, memorable, so since ancient times, there are countless writers and artists frequently quoted or borrowed language of the Bible. Visible, the Bible and its own culture in the history of the English language has played an invaluable role. Bible culture and English language though are two different concepts, but the former is largely restricted the latter's Style and development trend to bring the indelible traces of the Bible; the latter is the former carrier, it which reflects both the English language culture, life style of society, but also consciously or unconsciously adjust their forms to adapt to this culture, and the further spread of this culture.

\section{Reference:}

[1] Deng Huan, Zhang Chun. Source of English Allusions and Applying the Principles [J]. Leshan Teachers College, 2012 (7).

[2] Gao Guifang. English Textbooks Bible Allusions and Teaching [J]. Hengshui Teachers College, 2011 (4).

[3] Zhu Jianxin. Biblical Allusions Example Captures Jane [J]. Science English Learning, 2011 (3).

[4] Wang Xiaohuang. On Shakespeare Biblical Allusions [J]. Liaoning Teachers College, 2010 (3). 